\title{
Pengaruh return on assets, total assets turnover dan inventory turnover terhadap perubahan laba
}

\author{
Puput Ratnasiwi ${ }^{1}$, Ahmad Idris ${ }^{2}$ \\ ${ }^{1,2}$ Program Studi Manajemen, Fakultas Ekonomi, Universitas Islam Kadiri, Kediri, 64128, Indonesia
}

\begin{tabular}{|c|c|}
\hline INFO ARTIKEL & ABSTRAK \\
\hline $\begin{array}{l}\text { Kata kunci: } \\
\text { Return on assets, total } \\
\text { assets turnover, } \\
\text { inventory turnover, } \\
\text { perubahan laba }\end{array}$ & $\begin{array}{l}\text { Tujuan penelitian ini untuk mengetahui pengaruh return on assets, } \\
\text { total assets turnover dan inventory turnover terhadap perubahan laba } \\
\text { pada perusahaan kosmetik dan keperluan rumah tangga yang terdaftar } \\
\text { di Bursa Efek Indonesia. Metode penentuan sampel yang digunakan } \\
\text { adalah purposive sampling. Sampel yang digunakan yaitu laporan } \\
\text { keuangan perusahaan kosmetik dan keperluan rumah tangga dari } \\
\text { tahun } 2013 \text { sampai } 2018 \text {. Teknik analisis yang digunakan dalam } \\
\text { penelitian ini adalah analisis regresi linier berganda. Hasil pengujian } \\
\text { menunjukkan bahwa secara parsial terdapat pengaruh positif dan } \\
\text { signifikan antara return on assets terhadap perubahan laba, secara } \\
\text { parsial terdapat pengaruh negatif dan signifikan antara total assets } \\
\text { turnover terhadap perubahan laba dan tidak terdapat pengaruh antara } \\
\text { inventory turnover terhadap perubahan laba. Variabel return on assets } \\
\left.\text { ( } \mathrm{X}_{1}\right) \text {, total assets turnover ( } \mathrm{X}_{2} \text { ) dan inventory turnover ( } \mathrm{X}_{3} \text { ) secara } \\
\text { simultan (bersama-sama) berpengaruh signifikan terhadap perubahan } \\
\text { laba. }\end{array}$ \\
\hline
\end{tabular}

\begin{tabular}{|c|c|}
\hline ARTICLE INFO & ABSTRACT \\
\hline $\begin{array}{l}\text { Keywords: } \\
\text { Return on assets, total } \\
\text { assets turnover; } \\
\text { inventory turnover, } \\
\text { changes in income }\end{array}$ & $\begin{array}{l}\text { The purpose of this study is to know the effect of return on assets, total } \\
\text { assets turnover and inventory turnover to changes in income of } \\
\text { cosmetics and household goods companies which is listed on the } \\
\text { Indonesia Stock Exchange 2013-2018. The sampling method used is } \\
\text { purposive sampling. The sample used is yearly financial statements } \\
\text { from 2013-2018. The analysis technique used in this study is multiple } \\
\text { linear regression analysis. The test results show that partially there is } \\
\text { positive influence between return on assets to changes in income, there } \\
\text { is negative influence between total assets turnover to changes in } \\
\text { income, and there is no influence between inventory turnover to } \\
\text { changes in income. The variable return on assets }\left(X_{1}\right) \text {, total assets } \\
\text { turnover }\left(X_{2}\right) \text {, and inventory turnover }\left(X_{3}\right) \text { simultaneously (together) } \\
\text { have significant effect to changes in income. }\end{array}$ \\
\hline
\end{tabular}

Korespondensi Penulis: Program Studi Manajemen Fakultas Ekonomi, Universitas Islam Kadiri, Jalan Sersan Suharmadji No. 38, Manisrenggo, Kediri 64128, Indonesia. E-mail: puputrtnsw@gmail.com ${ }^{1}$ 


\section{Pendahuluan}

Setiap perusahaan senantiasa menginginkan usahanya berkembang, termasuk pada perusahaan sub sektor kosmetik dan barang keperluan rumah tangga. Perusahaan sub sektor kosmetik dan barang keperluan rumah tangga merupakan perusahaan yang bergerak dalam produksi kosmetik, produk perawatan rambut, produk perawatan tubuh, produk perawatan rumah, dan produk makanan dan minuman.

Setidaknya terdapat tujuh perusahaan yang bergabung dalam Bursa Efek Indonesia dengan waktu yang tidak bersamaan pada sub sektor tersebut. Perusahaan-perusahaan tersebut antara lain, PT. Akasha Wira International Tbk., PT. Kino Indonesia Tbk., PT. Cottonindo Ariesta Tbk., PT. Martina Berto Tbk., PT. Mustika Ratu Tbk., PT. Mandom Indonesia Tbk., dan PT. Unilever Indonesia Tbk.

Meningkatnya pertumbuhan penduduk di Indonesia menyebabkan permintaan akan produk kosmetik dan barang keperluan rumah tangga semakin naik. Hal ini menjadikan perkembangan industri kosmetik dan barang keperluan rumah tangga semakin meningkat dan memiliki peluang investasi yang bagus. Kosmetik dan barang keperluan rumah tangga sendiri mempunyai peranan yang penting dalam kehidupan manusia. Saat ini kosmetik dan barang keperluan rumah tangga menjadi salah satu kebutuhan yang sangat diperlukan oleh masyarakat untuk menunjang penampilan, sehingga perkembangan industri kosmetik dan barang keperluan rumah tangga dapat berkembang dengan pesat di Indonesia dan menjadi peluang bisnis yang begitu menjanjikan untuk dikembangkan serta memiliki peluang investasi yang besar.

Suatu perusahaan dapat dikatakan mencapai kesuksesan dan berhasil memenangkan persaingan dengan perusahaan lain ketika dapat menghasilkan laba yang tinggi. Kenaikan atau penurunan laba disebut dengan perubahan laba. Perubahan laba yang terus meningkat dari tahun ke tahun akan memberikan sinyal yang positif mengenai kinerja keuangan suatu perusahaan. Untuk meningkatkan laba dibutuhkan perencanaan dan pengendalian keuangan yang baik. Perubahan laba yang tidak stabil menjadi kendala bagi kelangsungan suatu perusahaan.

Perlu diadakan suatu penelitian terhadap perubahan laba untuk mengetahui perkiraan mengenai pertumbuhan atau perubahan kondisi keuangan suatu perusahaan, sehingga dapat mengevaluasi apa saja yang telah dihasilkan perusahaan di masa lalu dan di masa yang sedang berjalan atau dimasa yang akan datang. Salah satu cara mengetahui tingkat laba dengan menggunakan profitabilitas.

Profitabilitas merupakan salah satu alat analisis untuk mengetahui laba yang diperoleh perusahaan. Salah satu rasio profitabilitas yang digunakan adalah return on assets yang merupakan rasio untuk mengukur seberapa efisien suatu perusahaan dalam mengelola asetnya untuk menghasilkan laba selama suatu 
periode. Sedangkan rasio aktivitas adalah rasio yang digunakan untuk mengukur tingkat efisiensi atau menilai kemampuan perusahaan dalam melaksanakan aktivitas sehari-hari.

Rasio aktivitas yang digunakan antara lain total assets turnover merupakan rasio yang menunjukkan kemampuan aktiva perusahaan dalam menghasilkan total penjualan bersih sedangkan inventory turnover merupakan rasio untuk mengukur efisiensi perusahan dalam mengelola dan menjual persediaan.

Penelitian ini bertujuan untuk mengetahui pengaruh return on assets, total assets turnover dan inventory turnover terhadap perubahan laba pada perusahaan kosmetik dan keperluan rumah tangga yang terdaftar di Bursa Efek Indonesia periode 2013-2018.

\section{Tinjauan Pustaka dan Pengembangan Hipotesis}

\subsection{Return on assets (ROA)}

Menurut Harahap (2013), Return On Asset merupakan rasio yang menunjukan berapa besar laba bersih diperoleh bila diukur dari nilai aktiva dengan cara membagi laba bersih yang didapar dengan rata-rata total aset perusahaan. Semakin besar ROA perusahaan, semakin besar pula posisi perusahaan tersebut dan semakin baik pula posisi perusahaan tersebut dari segi penggunaan aset. Rumus yang digunakan untuk menghitung ROA menurut Brigham \& Houston (2006) adalah:

$$
\text { ROA }=\frac{\text { Laba bersih }}{\text { Total Aset }}
$$

\subsection{Total Assets Turnover (TATO)}

Total asset turnover mengukur efektivitas penggunaan seluruh aktiva dalam menghasilkan penjualan, dan semakin besar rasio ini maka semakin efektif pengelolaan seluruh aktiva yang dimiliki perusahaan. Rumus yang digunakan untuk menghitung TATO menurut Sumarsan (2013) adalah:

$$
\text { TATO }=\frac{\text { Penjualan Bersih }}{\text { Total Aktiva }}
$$

\subsection{Inventory Turnover (ITO)}

Menurut Suharli (2006) Perputaran persediaan menentukan berapa kali persediaan (inventory) terjual atau digantikan dengan persediaan yang baru selama satu tahun, dan memberikan beberapa pengukuran mengenai likuiditas dan kemampuan suatu perusahaan untuk mengkonversikan barang persediaannya menjadi uang secara tepat. Rumus yang digunakan untuk menghitung ITO menurut Kasmir (2013) adalah:

$$
\text { ITO }=\frac{\text { Penjualan }}{\text { Persediaan }}
$$

\subsection{Perubahan Laba}

Menurut Munawir (2007), pertumbuhan laba merupakan peningkatan dan penurunan laba yang diperoleh perusahaan dibandingkan dengan tahun sebelumnya. Rumus yang digunakan untuk menghitung perubahan laba menurut Munawir (2007) adalah:

$$
\Delta \mathrm{Yit}=\frac{\mathrm{Yit}-\mathrm{Y}(\mathrm{it}-1)}{\mathrm{Y}(\mathrm{it}-1)}
$$




\subsection{Return on assets dan perubahan laba}

ROA digunakan untuk mengukur seberapa besar jumlah laba bersih yang akan didapatkan dari setiap rupiah dana yang tertanam dalam total aset. Semakin tinggi hasil pengembalian atas aset menunjukkan semakin tinggi juga jumlah laba bersih yang didapatkan dari setiap rupiah dana yang tertanam didalam total asset. Semakin rendah hasil pengembalian atas aset berarti semakin rendah juga jumlah laba bersih yang dihasilkan dari setiap rupiah dana yang tertanam dalam total aset.

Hipotesis 1. ROA berpengaruh positif terhadap perubahan laba.

\subsection{Total asset turnover dan perubahan laba}

Total Asset Turn Over merupakan salah satu rasio aktivitas yang menunjukkan efisiensi dari penggunaan seluruh aktiva suatu perusahaan untuk menunjang penjualan. Semakin tinggi Total Asset Turn Over berarti perusahaan dalam menggunakan seluruh aktiva perusahaan untuk menghasilkan penjualan bersihnya secara efisien. Semakin cepat perputaran aktiva suatu perusahaan untuk menunjang kegiatan penjualan bersihnya, maka pendapatan diperoleh meningkat sehingga laba yang didapat besar. Sebaliknya ketika nilai TATO rendah, maka kemampuan perusahaan dalam menghasilkan laba juga menurun dan artinya laba perusahaan menurun dan perubahan laba yang terjadi pada perusahaan juga akan menurun.

Hipotesis 2. TATO berpengaruh positif terhadap perubahan laba.

\subsection{Inventory turnover dan perubahan laba}

Inventory Turnover merupakan rasio yang digunakan untuk mengukur efesiensi perusahaan dalam mengelola serta menjual suatu persediaan. Semakin tinggi rasio perputaran persedian berarti modal kerja yang tertanam dalam persediaan barang dagang semakin kecil dan hal ini berarti semakin baik bagi perusahaan. Dikatakan semakin baik karena lamanya penjualan persediaan barang dagang semakin cepat sehingga perusahaan tidak terlalu lama menunggu dananya yang tertanam dalam persediaan barang dagang untuk dapat dicairkan menjadi uang kas.

Hipotesis 3. Inventory turnover berpengaruh positif terhadap perubahan laba.

\subsection{Model Penelitian}

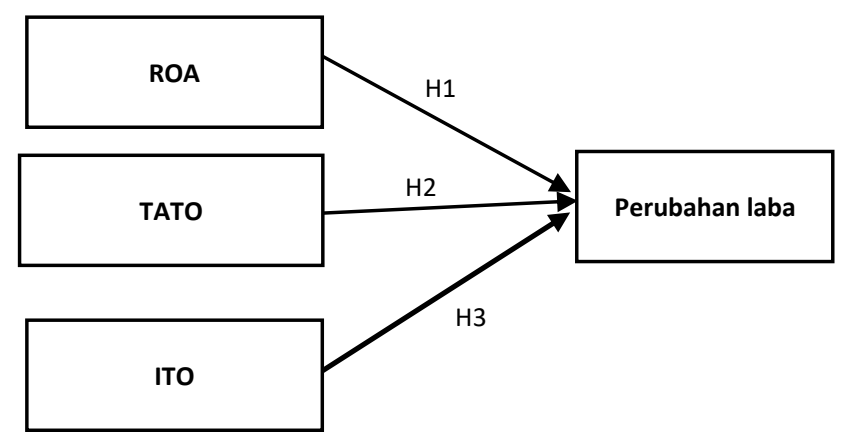

Gambar 1. Model Penelitian

Dari pembentukan hipotesis dibuat model penelitian pada Gambar. 1.

\section{Metodologi}

Penelitian ini merupakan penelitian kuantitatif. Jenis data yang digunakan dalam penelitian ini adalah data sekunder. Populasi dalam penelitian ini adalah seluruh laporan keuangan perusahaan kosmetik dan keperluan 
rumah tangga yang terdaftar di Bursa Efek Indonesia.

\subsection{Sampel dan pengumpulan data}

Teknik pengambilan sampel dalam penelitian ini adalah teknik purposive sampling. Menurut Margono (2004), pemilihan sekelompok subjek dalam purposive sampling, didasarkan atas ciri-ciri tertentu yang dipandang mempunyai sangkut paut yang erat dengan ciriciri populasi yang sudah diketahui sebelumnya. Degan kata lain unit sampel yang dihubungi disesuaikan dengan kriteria-kriteria tertentu yang diterapkan berdasarkan tujuan penelitian.

$$
\text { Kriteria yang digunakan yaitu: 1) }
$$

Perusahaan kosmetik dan keperluan rumah tangga yang terdaftar di BEI periode 2013-2018;

2) Perusahaan kosmetik dan keperluan rumah tangga yang mengeluarkan data laporan keuangan selama 6 tahun terakhir.

Berdasarkan kriteria yang telah ditetapkan di atas, maka jumlah sampel dalam penelitian ini sejumlah 30 laporan keuangan dari 5 perusahaan selama 6 tahun.

Tabel 1. Jumlah Sampel Laporan Keuangan

\begin{tabular}{|c|c|c|}
\hline Saham & Tahun & Data \\
\hline ADES & $2013-2018$ & 6 \\
\hline MBTO & $2013-2018$ & 6 \\
\hline MRAT & $2013-2018$ & 6 \\
\hline TCID & $2013-2018$ & 6 \\
\hline UNVR & $2013-2018$ & 6 \\
\hline \multicolumn{2}{|c|}{ Jumlah N } & 30 \\
\hline
\end{tabular}

Sumber: BEI, 2020

\subsection{Definisi Operasional Variabel}

Definisi operasional variabel dalam penelitian ini seperti tabel 2 .

Tabel 2. Definisi Operasional Variabel

\begin{tabular}{|c|c|c|c|}
\hline Variabel & Proksi & Skala & Sumber \\
\hline $\begin{array}{l}\text { ROA } \\
\text { (X1) }\end{array}$ & ROA $=\frac{\text { Laba bersih }}{\text { Total Aset }}$ & Rasio & $\begin{array}{l}\text { Brigham \& } \\
\text { Houston } \\
\text { (2006) }\end{array}$ \\
\hline $\begin{array}{l}\text { TATO } \\
(\mathrm{X} 2)\end{array}$ & $\begin{array}{c}\text { TATO }= \\
\text { Penjualan Bersih } \\
\text { Total Aktiva }\end{array}$ & Rasio & $\begin{array}{l}\text { Sumarsan } \\
(2013)\end{array}$ \\
\hline ITO (X3) & ITO $=\frac{\text { Penjualan }}{\text { Persediaan }}$ & Rasio & $\begin{array}{l}\text { Kasmir } \\
(2013)\end{array}$ \\
\hline $\begin{array}{c}\text { PER. } \\
\text { LABA (Y) }\end{array}$ & $\Delta$ Yit $=\frac{\text { Yit }-Y(\text { it }-1)}{Y(\text { it }-1)}$ & Nominal & $\begin{array}{l}\text { Munawir } \\
(2007)\end{array}$ \\
\hline
\end{tabular}

Sumber: Peneliti, 2020

\subsection{Teknik Analisis}

\section{Uji Asumsi Klasik}

Untuk mengetahui apakah model regresi benar-benar menunjukkan hubungan yang signifikan dan representatif, maka model tersebut harus memenuhi asumsi klasik regresi. Uji asumsi klasik yang dilakukan adalah uji normalitas, multikolinearitas, autokorelasi, dan heteroskedastisitas.

\section{Uji Normalitas}

Menurut Ghozali (2005), uji normalitas bertujuan untuk menguji apakah dalam model regresi, variabel terikat dan variabel bebas keduanya mempunyai distribusi normal atau tidak. Model regresi yang baik adalah apabila keduanya mempunyai distribusi normal atau mendekati normal. Pada prinsipnya normalitas dapat dideteksi dengan melihat penyebaran data (titik) pada gambar dari grafik normal probablity plot. Jika titik-titik menyebar di sekitar garis diagonal maka data tersebut berdistribusi normal.

\section{Uji Multikolinearitas}


Uji multikolinearitas bertujuan untuk menguji apakah model regresi ditemukan adanya korelasi antar variabel bebas (independent). Menurut Ghozali (2005), uji multikolinearitas digunakan untuk mengetahui apakah dalam model regresi ditemukan ada atau tidaknya korelasi antar variable bebas, model yang baik seharusnya tidak terjadi korelasi yang tinggi diantara variabel bebas. Uji multikolinearitas ini dapat dilihat dari nilai Tolerance dan Variance Inflation Factor (VIF). Nilai Tolerance di atas (>) 0,1 dan nilai VIF di bawah (<) 10 .

\section{Uji Autokorelasi}

Menurut Priyatno (2010), kriteria pengambilan keputusan untuk mendeteksi ada tidaknya autokorelasi pada uji Durbin Watson adalah sebagai berikut: 1) DU < DW < 4-DU maka Ho diterima, artinya tidak terjadi autokorelasi; 2) DW $<$ DL atau DW $>4$-DL maka Ho ditolak, artinya terjadi autokorelasi; 3) DL < DW < DU atau 4-DU $<$ DW < 4-DL, artinya tidak ada kepastian atau kesimpulan yang pasti.

\section{Uji Heteroskedastisitas}

Uji heteroskedastisitas dapat dilakukan dengan menggunakan uji Scatterplot yaitu dengan menguji tingkat signifikansinya. Dasar pengambilan keputusan dari uji scatterplot yaitu: 1) Jika ada pola tertentu seperti titik-titik yang membentuk suatu pola tertentu yang terartur (bergelombang, menyebar, dan menyempit) maka terjadi heterokedastisitas; 2) Jika tidak ada pola yang jelas seperti titik-titik meneyebar diatas dan dibawah angka 0 pada sumbu Y, maka tidak terjadi heteroskedastisitas.

\section{Analisis Regresi Linier Berganda}

Analisis regresi berganda harus digunakan untuk menguji pengaruh antara variabel independen yaitu Return on Assets, Total Asset Turn Over, dan Inventory Turnover terhadap perubahan laba sebagai variabel dependen. Persamaan regresi dapat dituliskan sebagai berikut:

$Y=\alpha+\beta_{1} X_{1}+\beta_{2} X_{2}+\beta_{3} X_{3+} e$

$\mathrm{Y} \quad$ : Perubahan laba

$\mathrm{X}_{1} \quad:$ Return On Assets

$\mathrm{X}_{2} \quad:$ Total Assets Turnover

$\mathrm{X}_{3} \quad:$ Inventory Turnover

$\alpha \quad$ : Konstanta

$\beta_{1 . .} \beta_{2 . .} \beta_{3} \quad:$ Koefisien regresi

$\mathrm{e} \quad:$ Error

\section{Uji Hipotesis}

Uji parsial (Uji t) dilakukan untuk menguji signifikansi pengaruh variabel-variabel independen, yaitu Return on Assets, Total Assets Turnover, dan Inventory Turnover secara individual terhadap variabel dependen, yaitu perubahan laba pada perusahaan kosmetik dan keperluan rumah tangga.

Dalam pengujian ini dilakukan dengan menggunakan signifikan 0,05 yaitu : 1) Apabila nilai siginifikan > 0,05 maka HO diterima $\mathrm{H} 1$ ditolak, dengan ini menunjukkan bahwa tidak adanya pengaruh yang signifikan antara variabel bebas (independen) terhadap variabel terikat (dependen) secara parsial; 2) Apabila nilai signifikan < 0,05 maka HO ditolak dan H1 diterima, dengan ini menunjukkan bahwa adanya pengaruh yang signifikan antara variabel bebas (independen) terhadap variabel terikat (dependen) secara parsial. 


\section{Hasil}

\subsection{Analisis Statistik Deskriptif}

\section{Perhitungan ROA}

Tabel 3. Perhitungan ROA

\begin{tabular}{|l|r|r|r|r|r|r|}
\hline \multirow{2}{*}{ Saham } & \multicolumn{7}{|c|}{ ROA \% } \\
\cline { 2 - 7 } & $\mathbf{2 0 1 3}$ & $\mathbf{2 0 1 4}$ & $\mathbf{2 0 1 5}$ & $\mathbf{2 0 1 6}$ & $\mathbf{2 0 1 7}$ & \multicolumn{1}{c|}{$\mathbf{2 0 1 8}$} \\
\hline ADES & 12,62 & 6,14 & 5,03 & 7,29 & 4,55 & 6,01 \\
\hline MBTO & 2,64 & 0,47 & $-2,17$ & $-1,24$ & $-3,16$ & $-17,61$ \\
\hline MRAT & 1,52 & $-1,48$ & 0,21 & $-1,15$ & 0,26 & $-0,44$ \\
\hline TCID & 10,92 & 9,41 & 26,15 & 7,42 & 7,58 & 7,08 \\
\hline UNVR & 40,10 & 40,18 & 37,20 & 38,16 & 37,05 & 46,66 \\
\hline
\end{tabular}

Sumber: Data Diolah, 2020

Berdasarkan tabel 3, Return On Assets tertinggi dimiliki oleh perusahaan Unilever Indonesia Tbk (UNVR) pada tahun 2018 sebesar 46,66. Secara keseluruhan kemampuan aset perusahaan dalam menghasilkan laba dari aktivitas perusahaannya terhitung baik terlihat dari rasio $R O A$ perusahaan yang tinggi. Semakin tinggi ROA perusahaan, semakin tinggi pula posisi perusahaan tersebut dan semakin baik pula posisi perusahaan tersebut dalam segi penggunaan aset. Semakin tinggi hasil pengembalian atas aset berarti semakin tinggi jumlah laba bersih yang akan dihasilkan dari setiap dana rupiah yang tertanam dalam total aset.

Sedangkan $R O A$ yang paling rendah yang dicapai oleh perusahaan Martina Berto Tbk (MBTO) pada tahun 2018 sebesar $-17,61$. Hal ini menunjukan bahwa semakin rendah hasil pengembalian atas aset berarti semakin rendah juga jumlah laba bersih yang dihasilkan yang tertanam dalam total aset.

Berdasarkan tabel 4, hasil perhitungan Total Assets Turover tertinggi dimiliki oleh perusahaan Unilever Indonesia Tbk (UNVR) pada tahun 2014 sebesar 2,42. Hal ini menunjukkan bahwa perusahaan tersebut dapat menggunakan aktivanya secara efektif untuk menghasilkan penjualan bersihnya dimana semakin semakin cepat perputaran aktiva suatu perusahaan untuk menunjang penjualan bersihnya maka pendapatan yang diperolehpun meningkat sehingga laba yang didapat besar.

\section{Perhitungan TATO}

Tabel 4. Perhitungan TATO

\begin{tabular}{|c|c|c|c|c|c|c|}
\hline \multirow{2}{*}{$\begin{array}{c}\text { Kode } \\
\text { Saham }\end{array}$} & \multicolumn{7}{|c|}{ TATO } \\
\cline { 2 - 7 } & $\mathbf{2 0 1 3}$ & $\mathbf{2 0 1 4}$ & $\mathbf{2 0 1 5}$ & $\mathbf{2 0 1 6}$ & $\mathbf{2 0 1 7}$ & $\mathbf{2 0 1 8}$ \\
\hline ADES & 1,14 & 1,15 & 1,03 & 1,16 & 0.97 & 0,91 \\
\hline MBTO & 1,05 & 1,08 & 1,07 & 0,97 & 0,94 & 0,78 \\
\hline MRAT & 0,81 & 0,87 & 0,86 & 0,71 & 0,69 & 0,59 \\
\hline TCID & 1,38 & 1,25 & 1,11 & 1,16 & 1,15 & 1,08 \\
\hline UNVR & 2,30 & 2,42 & 2,32 & 2,39 & 2,18 & 2,14 \\
\hline
\end{tabular}

Sumber: Data Diolah, 2020

Sedangkan hasil Total Assets Turnover paling rendah dimiliki oleh perusahaan Mustika Ratu Tbk pada tahun 2018 sebesar 0,59. Hal ini menunjukan perputaran aset perusahaan semakin sedikit, sehingga perusahaan semakin lambat dalam menggunakan asetnya untuk penjualan.

\section{Perhitungan ITO}

Tabel 5. Perhitungan ITO

\begin{tabular}{|c|c|c|c|c|c|c|}
\hline \multirow{2}{*}{$\begin{array}{c}\text { Kode } \\
\text { Saham }\end{array}$} & \multicolumn{7}{|c|}{ ITO } \\
\cline { 2 - 7 } & $\mathbf{2 0 1 3}$ & $\mathbf{2 0 1 4}$ & $\mathbf{2 0 1 5}$ & $\mathbf{2 0 1 6}$ & $\mathbf{2 0 1 7}$ & $\mathbf{2 0 1 8}$ \\
\hline ADES & 5,93 & 6,26 & 6,75 & 9,30 & 7,54 & 7,37 \\
\hline MBTO & 12,04 & 8,95 & 9,06 & 7,28 & 7,07 & 4,73 \\
\hline MRAT & 5,26 & 5,03 & 5,42 & 3,80 & 3,14 & 2,38 \\
\hline TCID & 6,14 & 5,50 & 6,05 & 5,13 & 6,40 & 4,88 \\
\hline UNVR & 14,76 & 14,84 & 15,88 & 17,28 & 17,21 & 15,73 \\
\hline
\end{tabular}

Sumber: Data Diolah, 2020

Berdasarkan tabel 5, hasil perhitungan Inventory Turnover tertinggi dimiliki perusahaan Unilever Indonesia Tbk (UNVR) pada tahun 2016 sebesar 17,28. Hal ini menunjukkan bahwa perusahaan dapat melakukan penjualan secara maksimum sehingga persediaan cepat berkurang 
yang berarti menambah pendapatan serta keuntungan dalam perusahaan tersebut. Sedangkan hasil Inventory Turnover terendah dimiliki Mustika Ratu Tbk (MRAT) pada tahun 2018 sebesar 2,38. Hal ini menunjukan bahwa penjualan menurun sehingga persediaan yang ada tidak dapat cepat terjual serta menambah tingkat keusangan barang sehingga perusahaan tidak efisien dalam melakukan manajemen persediaan.

\section{Perhitungan Perubahan Laba}

Tabel 6. Perhitungan Perubahan Laba

\begin{tabular}{|c|c|c|c|c|c|c|}
\hline \multirow{2}{*}{$\begin{array}{c}\text { Kode } \\
\text { Saham }\end{array}$} & \multicolumn{7}{|c|}{ Perubahan Laba } \\
\cline { 2 - 7 } & $\mathbf{2 0 1 3}$ & $\mathbf{2 0 1 4}$ & $\mathbf{2 0 1 5}$ & $\mathbf{2 0 1 6}$ & $\mathbf{2 0 1 7}$ & $\mathbf{2 0 1 8}$ \\
\hline ADES & $-0,23$ & $-0,30$ & 0,06 & 0,40 & $-0,17$ & 0,37 \\
\hline MBTO & $-0,61$ & $-0,75$ & 1,95 & $-1,70$ & 1,69 & 3,90 \\
\hline MRAT & $-0,47$ & $-2,00$ & $-0,78$ & 0,81 & $-1,33$ & $-2,38$ \\
\hline TCID & 0,07 & 0,10 & 1,44 & $-0,62$ & 0,10 & $-0,03$ \\
\hline UNVR & 0,11 & 0,07 & 0,02 & 0,09 & 0,09 & 0,30 \\
\hline
\end{tabular}

Sumber: Data Diolah, 2020

Berdasarkan tabel 6 , hasil perhitungan Perubahan laba tertinggi dimiliki perusahaan Martina Berto Tbk (MBTO) pada tahun 2018 sebesar 3,90. Sedangkan hasil Perubahan Laba terendah dimiliki perusahaan Mustika Ratu Tbk (MRAT) pada tahun 2018 sebesar -2,38.

\subsection{Hasil Uji Asumsi Klasik}

\section{Hasil Uji Normalitas}

Pada uji normalitas terdapat beberapa metode yang bisa digunakan untuk mendeteksi masalah normalitas yang salah satunya adalah Probality Plot. Dalam uji ini dapat diketahui dengan adanya penyebaran data (titik) pada sumbu diagonal pada grafik.
Normal P.p plot of Regression standardized Residual

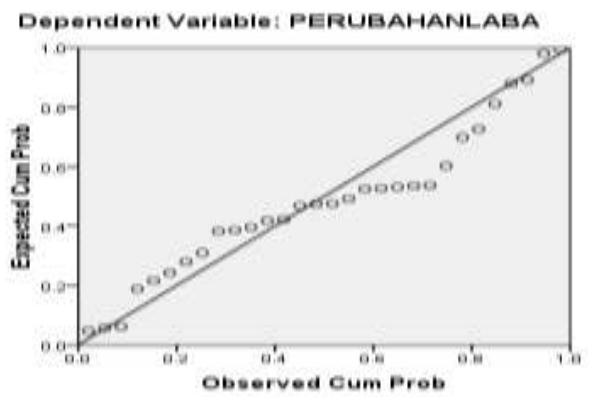

Gambar 2. Grafik P Plot.

Berdasarkan gambar diatas dapat disimpulkan bahwa data (titik) menyebar disekitar garis diagonal dan mengikuti garis diagonal, sehingga dapat disimpulkan bahwa model regresi pada penelitian ini memenuhi asumsi asumsi normalitas atau data berdistribusi normal.

\section{Hasil Uji Multikolinearitas}

Tabel 7. Uji Multikolinearitas

\begin{tabular}{|l|c|c|}
\hline \multirow{2}{*}{ Variabel } & \multicolumn{2}{|c|}{ Colliniearity Statistics } \\
\cline { 2 - 3 } & Tolerance & VIF \\
\hline ROA & 0.188 & 5.330 \\
\hline TATO & 0.104 & 9.588 \\
\hline ITO & 0.200 & 5.003 \\
\hline
\end{tabular}

Sumber: Data Diolah, 2020

Berdasarkan tabel 7, diatas nilai VIF kurang dari 10 dari keseluruhan variabel penelitian return on assets sebesar 5,330, total assets turnover sebesar 9,588 dan inventory turnover sebesar 5,003 sehingga dapat disimpulkan bahwa tidak terjadi gejala multikolinieritas antara variabel independen dalam model regresi pada penelitian ini.

\section{Hasil Uji Heterokedastisitas}




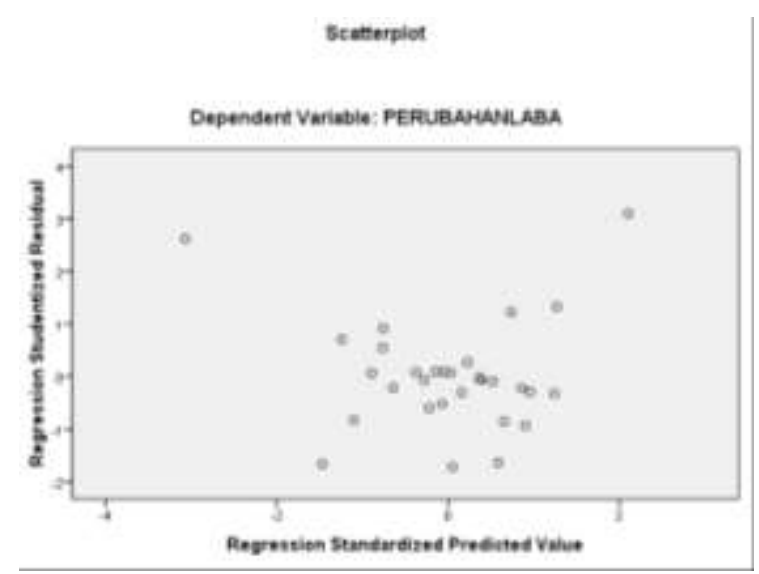

Gambar 3. Uji Heteroskedastisitas

Berdasarkan scatterplot pada gambar 3, diatas menjelaskan bahwa titik-titik koordinat menyebar secara acak atau tidak membentuk pola yang teratur. Maka dari data tersebut menunjukkan bahwa tidak terdapat gejala heterokedastisitas, sehingga model regresi tersebut bisa dipakai untuk memprediksi variabel perubahan laba.

\section{Hasil Uji Autokorelasi}

Tabel 8. Uji Autokorelasi

\begin{tabular}{|l|l|}
\hline Model & Durbin Watson \\
\hline 1 & 2.109 \\
\hline
\end{tabular}

Sumber: Data Diolah, 2020

Berdasarkan hasil uji autokorelasi pada tabel 8 di atas, dapat dilihat bahwa DurbinWatson sebesar 2,109 dimana nilai ini akan dibandingkan dengan derajat kepercayaan 5\% dan sampel berjumlah $30 \quad(n=30)$ dengan 3 variabel bebas $(k=3)$, maka besarnya DW tabel adalah $d u$ (batas dalam) =1,650 dan 4- $d u=2,350$. Dengan demikian $d u<d w<4-d u$ adalah 1,650< $2,109<2,350$, sehingga dapat disimpulkan tidak terjadi autokorelasi.

\subsection{Hasil Analisis Regresi Linier Berganda}

Dalam penelitian ini, metode analisis data yang digunakan adalah metode analisis regresi linear berganda. Data diolah dengan menggunakan SPSS versi 16 for windows yang berfungsi untuk mengetahui pengaruh variabel return on assets $\left(\mathrm{X}_{1}\right)$, total assets turnover $\left(\mathrm{X}_{2}\right)$ dan inventory turnover $\left(\mathrm{X}_{3}\right)$ terhadap perubahan laba (Y). Hasil perhitungan dapat dilihat pada tabel 9 di bawah.

Tabel 9. Hasil Analisis Linear Berganda

\begin{tabular}{|c|c|c|c|c|c|}
\hline \multirow{2}{*}{\multicolumn{2}{|c|}{ Model }} & \multicolumn{2}{|c|}{$\begin{array}{l}\text { Unstandardized } \\
\text { coefficients }\end{array}$} & \multirow{3}{*}{$\frac{t}{-4.162}$} & \multirow{3}{*}{$\begin{array}{l}\text { Sig. } \\
.002\end{array}$} \\
\hline & & \multirow{2}{*}{$\begin{array}{c}\text { B } \\
-7.884\end{array}$} & \multirow{2}{*}{$\begin{array}{l}\begin{array}{l}\text { Std. } \\
\text { Error }\end{array} \\
1.894\end{array}$} & & \\
\hline \multirow[t]{4}{*}{1.} & (Constant) & & & & \\
\hline & ROA & 2.026 & .474 & 4.275 & .002 \\
\hline & TATO & -6.970 & 1.456 & -4.788 & .001 \\
\hline & ITO & 1.381 & .887 & 1.556 & .154 \\
\hline \multicolumn{4}{|c|}{ a.Dependent Variable: Perubahan Laba } & & \\
\hline
\end{tabular}

Sumber: Data Diolah, 2020

Berdasarkan pada tabel 9, maka diperoleh persamaan regresi berganda sebagai berikut : $\mathrm{Y}=-7,884+2,026 \mathrm{X} 1-6,970 \times 2+1,381$ X3.

Nilai konstanta yang diperoleh sebesar 7,884 dapat diartikan apabila dari variabel independen (ROA, TATO dan ITO) tetap maka nilai dari variabel dependen yaitu perubahan laba akan bernilai sebesar -7,884. Konstanta negatif artinya terjadi penurunan perubahan laba perusahaan sebesar -7,884.

Return on Assets mempunyai koefisien regresi sebesar 2,026. Hal ini menunjukan bahwa setiap ada peningkatan Return on Assets sebesar satu satuan dan variabel lain tetap maka akan meningkatkan perubahan laba sebesar 2,026. Jadi terdapat pengaruh positif antara Return on Assets dan perubahan laba. 
Total Assets Turnover mempunyai koefisien regresi sebesar -6,970. Hal ini menunjukan bahwa setiap ada kenaikan total assets turnover sebesar satu satuan dan variabel lain tetap maka akan menurunkan perubahan laba sebesar -6,970. Jadi terdapat pengaruh negatif antara total assets turnover dengan perubahan laba.

Inventory Turnover mempunyai koefisien regresi sebesar 1,381. Hal ini menunjukkan bahwa setiap ada peningkatan Inventory Turnover sebesar satu satuan dan variabel lain tetap maka akan meningkatkan perubahan laba sebesar 1,381. Jadi terdapat pengaruh positif antara Inventory Turnover dan perubahan laba.

\subsection{Hasil Uji Hipotesis}

Tabel 10. Hasil Uji t

\begin{tabular}{|c|c|c|}
\hline \multirow{2}{*}{ Model } & $\begin{array}{c}\text { Unstandardized } \\
\text { Coefficients }\end{array}$ & \multirow{2}{*}{ Sig. } \\
\cline { 2 - 3 } & $\mathrm{B}$ & 0.002 \\
\hline (Constant) & -7.884 & 0.002 \\
\hline ROA & 2.026 & 0.001 \\
\hline TATO & -6.970 & 0.154 \\
\hline ITO & 1.381 & \\
\hline
\end{tabular}

Sumber: Data Diolah, 2020

Variabel return on assets memiliki nilai koefisien regresi sebesar 2,026. Dari hasil pengujian tersebut diperoleh bahwa tingkat signifikansi return on assets sebesar 0.002 yang artinya kurang dari 0,05. Sehingga dapat disimpulkan bahwa return on assets memiliki pengaruh yang positif dan signifikan antara variabel return on assets dengan perubahan laba.

Variabel total assets turnover memiliki nilai koefisien regresi sebesar - 6.970. dari hasil pengujian tersebut diperoleh tingkat signifikansi total assets turnover sebesar 0.001 yang artinya kurang dari 0,05. Sehingga dapat disimpulkan bahwa total assets turnover memiliki pengaruh yang negatif dan signifikan antara variabel total assets turnover dengan perubahan laba.

Variabel inventory turnover memiliki nilai koefisien regresi sebesar 1.381. Dari hasil pengujian tersebut diperoleh tingkat signifikansi inventory turnover sebesar 0.154 yang artinya lebih dari 0,05. Sehingga dapat disimpulkan bahwa inventory turnover positif dan tidak memiliki pengaruh yang signifikan antara variabel inventory turnover dengan perubahan laba.

\section{Pembahasan}

\subsection{Return on Assets terhadap perubahan laba}

Hasil analisis pada penelitian ini menunjukan bahwa variabel return on assets berpengaruh positif dan signifikan terhadap perubahan laba yang ditunjukkan dengan nilai signifikan sebesar 0,002 yang artinya kurang dari 0,05. Dengan demikian $\mathrm{HO}$ ditolak dan $\mathrm{H} 1$ diterima yang berarti return on assets ada pengaruh positif yang signifikan terhadap perubahan laba secara parsial.

Hal ini menunjukkan bahwa perusahaanperusahaan kosmetik dan keperluan rumah tangga mampu mengelola return on assets yang dimiliki sehingga mampu meningkatkan perubahan laba perusahaan. Dalam meningkatkan return on assets dapat dilakukan dengan meningkatkan pemanfaatan total aset yang dimiliki sehingga akan menambah laba bersih dimasa yang yang akan datang. Semakin 
tinggi hasil pengembalian atas aset berarti semakin tinggi pula jumlah laba bersih yang dihasilkan dari setiap rupiah dana yang tertanam dalam total aset. Hasil dalam penelitian ini konsisten dengan penelitian Bionda \& Mahdar (2017) yang menyatakan bahwa return on assets berpengaruh positif dan signifikan terhadap perubahan laba.

\subsection{Total Assets Turn Over terhadap perubahan} laba

Hasil analisis pada penelitian ini menunjukan bahwa variabel total assets turnover berpengaruh negatif dan signifikan terhadap perubahan laba yang ditunjukkan dengan nilai signifikan sebesar 0,001 yang artinya kurang dari 0,05. Dengan demikian HO ditolak dan $\mathrm{H} 2$ diterima yang berarti total assets turnover ada pengaruh yang negatif dan signifikan terhadap perubahan laba secara parsial.

Penelitian ini menunjukkan bahwa total assets turnover berpengaruh negatif dan signifikan terhadap perubahan laba perusahaan kosmetik dan keperluan rumah tangga. Nilai $\mathrm{t}$ dalam penelitian ini adalah negatif, dimana setiap kenaikan satu satuan total assets turnover maka akan menyebabkan penurunan perubahan laba. Pada saat total assets turnover mengalami penurunan maka diikuti oleh kenaikan atau penurunan perubahan laba. Hal tersebut disebabkan pada saat menggunakan aset yang tinggi, serta pengelolaan aktiva yang tidak efektif dan efisien, maka dalam menghasilkan penjualan bersih untuk mendapatkan laba akan menurun.
Hasil dalam penelitian ini konsisten dengan penelitian Putri \& Sitohang (2019) yang menyatakan bahwa total assets turnover berpengaruh negatif dan signifikan terhadap perubahan laba.

\subsection{Inventory Turn Over terhadap perubahan} laba

Hasil analisis pada penelitian ini menunjukan bahwa variabel inventory turnover berpengaruh positif dan tidak signifikan terhadap perubahan laba yang ditunjukkan dengan nilai signifikan sebesar 0,154 yang artinya lebih dari 0,05 . Dengan demikian HO diterima dan H3 ditolak yang berarti inventory turnover positif dan tidak ada pengaruh yang signifikan terhadap perubahan laba secara parsial.

Inventory turnover merupakan rasio yang digunakan untuk mengukur berapa kali dana yang ditanamkan dalam persediaan ini berputar dalam satu periode. Inventory turnover (perputaran persediaan) yang tinggi menandakan semakin tingginya persediaan berputar dalam satu tahun dan ini menandakan efektivitas manajemen persediaan. Hal ini berarti bahwa efektivitas perputaran persediaan yang dimiliki perusahaan sangat baik, sehingga persediaan yang dimiliki dapat meningkatkan aktivitas operasional perusahaan terutama dalam hal kemampuan untuk meningkatkan perubahan laba perusahaan. Namun nilai inventory turnover yang tinggi tidak selalu memiliki perubahan laba yang tinggi pula karena kemungkinan pengendalian persediaan yang dilakukan perusahaaan kurang efektif sehingga 
persediaan barang dagang tidak mampu dijual dengan cepat dan perusahaan menjadi lama menunggu dana yang tertanam dalam persediaan barang dagang untuk dapat dicairkan menjadi uang kas.

Hasil dalam penelitian ini konsisten dengan penelitian Wahyuni et al. (2017) yang menyatakan bahwa inventory turnover positif tidak signifikan terhadap perubahan laba.

\section{Kesimpulan dan Saran}

Return On Assets secara parsial berpengaruh positif dan signifikan pada perubahan pada perusahaan kosmetik dan keperluan rumah tangga yang terdaftar di Bursa Efek Indonesia periode 2013-2108. Total Assets Turnover secara parsial berpengaruh negatif dan signifikan pada perubahan pada perusahaan kosmetik dan keperluan rumah tangga yang terdaftar di Bursa Efek Indonesia periode 20132108. Inventory Turnover secara parsial berpengaruh positif dan tidak signifikan pada perubahan laba pada perusahaan kosmetik dan keperluan rumah tangga yang terdaftar di Bursa Efek Indonesia periode 2013-2108.

Saran bagi perusahaan, diharapkan lebih memperhatikan tingkat return on assets dan total assets turnover karena rasio tersebut cukup berdampak pada perubahan laba. Hal ini dapat dilihat melalui hasil yang diperoleh bahwa return on assets dan total assets turnover berpengaruh signifikan terhadap perubahan laba. Oleh karena itu, diharapkan perusahaan kosmetik dan keperluan rumah tangga mampu mengelola return on assets dan total assets turnover yang dimiliki sehingga mampu meningkatkan perubahan laba.

Bagi investor, dengan adanya penelitian ini diharapkan para investor akan lebih selektif dalam memilih perusahaan mana yang akan dijadikan tempat berinvestasi. Sebelum melakukan investasi dalam perusahaan kosmetik dan keperluan rumah tangga sangat disarankan untuk melihat kondisi keuangan perusahaan yang tercermin pada rasio-rasio keuangan khususnya return on assets dan total assets turnover karena rasio tersebut telah terbukti mempunyai pengaruh yang signifikan terhadap perubahan laba, dengan begitu investor akan mengetahui perusahaan mana yang memiliki kestabilan perubahan laba perusahaan yang nantinya akan menjadi hasil dari investasi yang dilakukan diperusahaan tersebut.

Bagi peneliti selanjutnya, yang berniat meneliti tentang return on assets, total assets turnover dan inventory turnover terhadap perubahan laba sebaiknya menambah rasio keuangan yang lain sebagai variabel independen/variabel bebas karena dapat dimungkinkan masih banyak faktor lain yang akan berpengaruh kuat terhadap perubahan laba. Selain itu peneliti selanjutnya perlu memperluas objek penelitian tidak hanya perusahaan kosmetik dan keperluan rumah tangga, namun juga perusahaan lain.

\section{Daftar Pustaka}

Bionda, A. R., \& Mahdar, N. M. (2017). Pengaruh Gross Profit Margin (GPM), Net Profit Margin (NPM), Return On Asset (ROA), dan 
Return On Equity (ROE) Terhadap

Pertumbuhan Laba Pada Perusahaan

Property Yang Terdaftar di Bursa Efek Indonesia (BEI) Periode 2012-2016. Jurnal Bisnis Dan Komunikasi, 4(1), 10-16.

Brigham, E. F., \& Houston, J. F. (2006). Dasardasar manajemen keuangan, edisi 11. Jakarta: Salemba Empat.

Ghozali, I. (2005). Aplikasi Analisis Multivariate Dengan SPSS. Semarang: Badan Penerbit UNDIP.

Harahap, S. S. (2013). Analisis Kritis Atas Laporan Keuangan. Jakarta: PT. Raja Grafindo Persada.

Kasmir. (2013). Analisis Laporan Keuangan. Jakarta: PT Raja Grafindo Persada.

Margono. (2004). Metodologi Penelitian Pendidikan. Jakarta: Rineka Cipta.

Munawir. (2007). Analisis Laporan Keuangan. Yogyakarta: Liberty.

Priyatno, D. (2010). Teknik Mudah dan Cepat Melakukan Analisis Data Penelitian dengan SPSS. Yogyakarta: Gava Media.

Putri, T. M., \& Sitohang, S. (2019). Pengaruh Current Ratio, Total Asset Turnover Dan Return on Asset Terhadap Pertumbuhan Laba. Jurnal Ilmu Dan Riset Manajemen, 8(6), 1-15.

Suharli, M. (2006). Akuntansi Untuk Bisnis Jasa Dan Dagang. Yogyakarta: Graha Ilmu.

Sumarsan, T. (2013). Sistem Pengendalian Manajemen: Konsep, Aplikasi, Dan
Pengukuran Kinerja (Cet. I). Jakarta: PT Indeks.

Wahyuni, T., Ayem, S., \& Suyanto, S. (2017). Pengaruh Quick Ratio, Debt To Equity Ratio, Inventory Turnover dan Net Profit Margin Terhadap Pertumbuhan Laba Pada Perusahaan Manufaktur Yang Terdaftar di Bursa Efek Indonesia Tahun 2011 - 2015. Jurnal Akuntansi Dewantara, 1(2), 117-126. 